Lorin, Bieb Ilemelong, Joycelyn Sicat, Francesca Sungino, James Ngiraremiang, Nixon Augustine, Basiano Kitalong, Wayne Yada, Fernando Tiakl, David Cepeda, Perry Sablan, and residents of Echang Hamlet and Sora Taima’s Barracks for their cooperation and participation in the surveys; Ismael Togamae, Laura Ierago, Sandra Pierantozzi, Victor Yano, and Tommy E. Remengesau Jr, for their support; and Mary Reynolds and John O’Connor for helpful manuscript comments.

Dr Demma completed 2 years as an Epidemic Intelligence Service officer at the Viral and Rickettsial Zoonosis Branch in the Division of Viral and Rickettsial Diseases at CDC. She is currently a senior epidemiologist for CDC's Foodborne Diseases Active Surveillance Network (FoodNet).

\section{References}

1. Traub R, Wisseman CL, Jones MR, O’Keefe JJ. The acquisition of Rickettsia tsutsugamushi by chiggers (trombiculid mites) during the feeding process. Ann N Y Acad Sci. 1975;266:91-114.

2. Traub R, Wisseman CL. The ecology of chigger-borne rickettsiosis (scrub typhus). J Med Entomol. 1974;11:237-303.

3. Lerdthunsee K, Khuntirat B, Leepitakrat W, Tanskul P, Monkanna T, Khlaimanee $\mathrm{N}$, et al. Scrub typhus: vector competence of Leptotrombidium chiangraiensis chiggers and transmission efficacy and isolation of Orientia tsutsugamushi. Ann N Y Acad Sci. 2003;990:25-35.

4. Watt G, Parola P. Scrub typhus and tropical rickettsioses. Curr Opin Infect Dis. 2003;16:429-36.

5. Silpapojakul K. Scrub typhus in the Western Pacific region. Ann Acad Med Singapore. 1997;26:794-800.
6. Corwin AL, Soeprapto W, Widodo PS, Rahardjo E, Kelly DJ, Dasch GA, et al. Short report: surveillance of rickettsial infections in Indonesian military personnel during peace keeping operations in Cambodia. Am J Trop Med Hyg. 1997;57:569-70.

7. Durand AM, Kuartei S, Togamae I, Marumoto P, Demma L, Nicholson WL, et al. Scrub typhus in the Republic of Palau, Micronesia. Emerg Infect Dis. 2004;10:1838-40.

8. Bozeman FM, Elisberg BL. Serological diagnosis of scrub typhus by indirect immunofluorescence. Proc Soc Exp Biol Med. 1963;112:568-73.

9. Dean AG, Arner TG, Sunki GG, Friedman R, Lantinga M, Sangam S, et al. EpiInfo, a database and statistics program for public health professionals. In: Series EpiInfo, a database and statistics program for public health professionals. Atlanta: Centers for Disease Control and Prevention; 2002.

10. Lemeshow S, Ronbinson D. Surveys to measure programme coverage and impact: a review of the methodology used by the expanded programme on immunization. World Health Stat Q. 1985;38:65-75.

11. Ashford DA, Savage HM, Hajjeh RA, Mcready J, Bartholomew DM, Spiegel RA, et al. Outbreak of dengue fever in Palau, Western Pacific: Risk factors for infection. Am J Trop Med Hyg. 2003;69:135-40.

12. Khuntirat B, Lerdthunsee K, Leepitakrat W, Kengluecha A, Wongkalasin K, Monkanna T, et al. Characterization of Orientia tsutsugamushi isolated from wild-caught rodents and chiggers in northern Thailand. Ann N Y Acad Sci. 2003;990:205-12.

Address for correspondence: Linda J. Demma, Foodborne Diseases Active Surveillance Network (FoodNet), Foodborne and Diarrheal Diseases Br, Centers for Disease Control and Prevention, 1600 Clifton Rd, Mailstop D63, Atlanta, GA USA 30333; fax: 404-371-5444; email: ldemma@cdc.gov

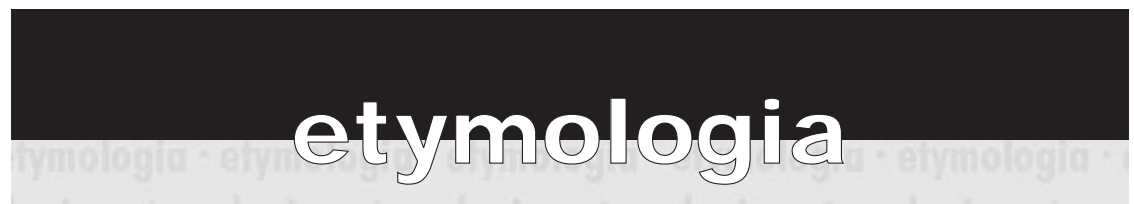

\title{
Orientia tsutsugamushi
}

$$
\text { [or"e-en'she-ə (t)süt"sə-gə-mü'she] }
$$

Etiologic agent of scrub typhus, transmitted by the bite of thrombiculid mite larvae. From the Latin oriens, "east" and the Japanese tsutsuga, "sickness" plus mushi, "insect." The disease was first documented in China in $313 \mathrm{AD}$ and has been a frequent cause of illness in soldiers stationed in the western Pacific. In Vietnam, O. tsutsugamushi was among the most common causes of fever in soldiers.

Sources: Dorland's illustrated medical dictionary. 30th ed. Philadelphia: Saunders; 2003; Merriam-Webster's collegiate dictionary. 11th ed. Springfield (MA): Merriam-Webster Incorporated; 2003; and Raoult D. Scrub typhus. In: Mandel GL, Bennett JE, Dolin R, editors. Principles \& Practice of Infectious Diseases. 6th ed. Churchill Livingstone; 2004. p. 2309-10.

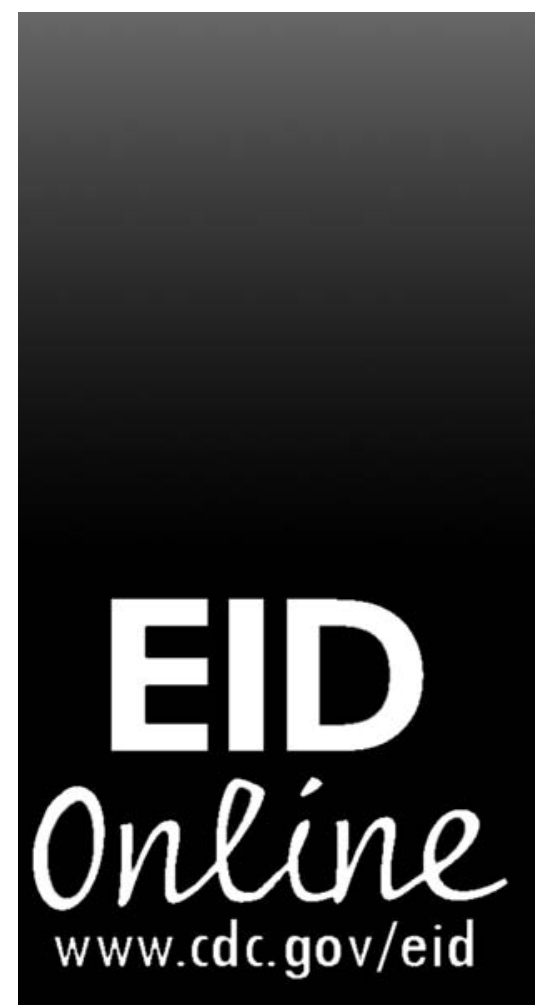

